\title{
RESEARCH ON THE PREPARATION AND PROFESSIONAL REALISATION OF NEWLY APPOINTED LOGISTICS OFFICERS
}

\author{
Nikolay NICHEV \\ “Vasil Levski” National Military University, Veliko Tarnovo, Bulgaria \\ nbnichev@nvu.bg
}

\begin{abstract}
The training and education of cadets at the Vasil Levski National Military University is aimed at professional, intellectual, physical and moral development, and creation of leadership and management skills. The education aims at realizing the concept of optimal receiving a wide range of competencies in the field of military affairs, as well as knowledge about the activities of civil, political, socio-economic structures and systems. It aims at forming knowledge, skills and moral and volitional qualities, which serve as a basis for professional development, allowing implementation of the system for national and collective security and defense. The officer is a leader with undivided personal authority who takes full responsibility for training and combat readiness of the personnel from the military unit entrusted to him, its education in patriotism and national pride, maintenance military discipline and moral-psychological condition, formation of a sense of duty and responsibility to Bulgarian homeland and nation, and responsibility to the state of armaments, military equipment, ammunition and other material resources.
\end{abstract}

\section{Keywords: professional realisation, logistics officers, leadership, management skills}

\section{Introduction}

The qualification characteristics of the syllabi for the training of future logistics officers have been discussed and approved by the Academic Council of the Vasil Levski National Military University. They provide the opportunity to practise the regulated profession Officer at Tactical Level of Management, and to acquire a bachelor's degree in the military and civilian specialty. For this purpose, the specialties "Organisation and Management of Military Units at Tactical Level" and "Logistics of Security" provide training according to a unified syllabus with a basic interdisciplinary, broad-profiled training for acquiring higher education in the military professional field of "Military studies", in the higher education area of "Security and Defence", as well as in the professional field of "Administration and Management", in the higher education area of "Social, Economic and Legal Sciences" [5].

According to the qualification characteristics, as a result of the overall military training at the university, the graduate:

A) is formed as a person with:

- developed leadership qualities and positive moral and volitional qualities;

- sufficient knowledge about military affairs, technical and social sciences, which allows a proper understanding of processes and phenomena in modern society;

- knowledge about economical, effective and efficient management of material, financial, human and information resources and logistical support;

- developed skills for management of platoons and companies in various conditions, allowing him/her to improve in management of larger military units; 
- developed intellectual and volitional qualities and ability to do research related to the security of the state and the local authorities;

- high general knowledge and communication skills.

B) must be prepared to complete the following tasks:

- to plan, organise and lead the combat training of the personnel, to maintain the necessary combat readiness of the entrusted unit;

- to participate, together with the military unit subordinated to him, in rescue operations and emergency rescue activities during natural disasters, industrial accidents, catastrophes and dangerous pollutions in the country;

- to participate in national and

\begin{tabular}{|c|c|}
\hline Types of training & Acquired knowledge \\
\hline \multicolumn{2}{|c|}{$\begin{array}{c}\text { First year of study } \\
\text { Beginning of training in military and civilian specialty }\end{array}$} \\
\hline $\begin{array}{l}\text { Basic military training } \\
\text { General education } \\
\begin{array}{l}\text { Fundamental training in } \\
\text { economics }\end{array}\end{array}$ & $\begin{array}{l}\text { On fundamental military skills; } \\
\text { On fundamental comprehensive support of operations; } \\
\text { General knowledge; } \\
\text { Fundamental knowledge in economics. }\end{array}$ \\
\hline \multicolumn{2}{|c|}{ Second year of study } \\
\hline \multicolumn{2}{|c|}{ Combined training in civilian and military specialty } \\
\hline $\begin{array}{l}\text { General military training } \\
\text { Special military training } \\
\text { Fundamental } \quad \text { management } \\
\text { training } \\
\begin{array}{l}\text { Fundamental } \\
\text { preparation }\end{array}\end{array}$ & $\begin{array}{l}\text { On logistical support of operations; } \\
\text { On exploitation of logistics and special equipment; } \\
\text { On the order for making statements of material resources; } \\
\text { On the basics of business logistics; } \\
\text { On the theory of economic management; } \\
\text { On standardisation and codification of the products; } \\
\text { On the marketing policy of business organisations. }\end{array}$ \\
\hline
\end{tabular}

\section{Third year of study}

Combined training in civilian and military specialty

Special military training

Specialised military training in logistical support

Specialised logistics training multinational combat operations and operations other than war.

- to be proactive and creative in dynamically changing conditions;

- to have psychological knowledge and skills for understanding the elements and applying the basic principles of effective leadership.

\section{Preparation of the cadets for management activity}

The acquisition of knowledge in different years of study occupies an important role in preparing cadets for management activity $[1,3]$. Figure 1 shows the process of preparedness for the military professional activity of future logistics officers. 


\begin{tabular}{|c|l|}
\hline Types of training & \multicolumn{1}{c|}{ Acquired knowledge } \\
\hline & $\begin{array}{l}\text { On management of supply; } \\
\text { On management of stocks. }\end{array}$ \\
\hline
\end{tabular}

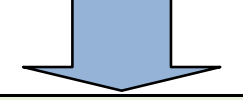

Fourth year of study

Combined training in civilian and military specialty

Graduation in civilian specialty

Specialised military training in On management of logistics support;

logistical support

Specialised military tactical

training

Specialised logistics training

On fundamental standardisation documents of NATO;

On the implementation of border and customs procedures;

On the management of product life cycle;

On the management of investment projects;

On the rules of business communication in logistics.

\begin{tabular}{|l|l|}
\hline \multicolumn{2}{|c|}{$\begin{array}{c}\text { Fifth year of study } \\
\text { Training in military specialty } \\
\text { Graduation in military specialty }\end{array}$} \\
\hline $\begin{array}{l}\text { Specialised military } \\
\text { training } \\
\text { National Security } \\
\text { Resource management } \\
\text { Law training }\end{array}$ & $\begin{array}{l}\text { On management of logistics units; } \\
\text { On procedure for planning, organising, conducting and } \\
\end{array}$ \\
& reporting of logistics preparation; \\
& On systems for logistics management; \\
& On military aspects of national security; \\
On risks and threats to national security; & On international security systems. \\
\hline
\end{tabular}

Figure 1: Formation of preparedness for the military professional activities of future logistics officers by years of training

During the fifth year of study, the dynamics in the preparation for the military occupation of the future logistics officers is the highest. A high degree of preparation for management activities and a high sense of responsibility are characteristic of the graduating cadets. At the end of the military training, cadets feel they are knowledgeable, capable and prepared to offer professional and appropriate solutions for particular tasks by themselves [4].

The annual reporting of the views of cadets by the Military Psychology section at the Vasil Levski National Military University is in support of this. The indicators and criteria for learning cadets' outcomes, namely the acquired knowledge and skills, are set in the annual report of the Military Psychology section at the National Military University for the 2015/2016 academic year
[2]. The main purpose of training at the Vasil Levski National Military University is the appropriate vocational training for future quality realisation. In this respect, graduates have the opportunity to assess their personal preparation for future professional activity using the following indicators: theoretical knowledge, practical training, mental preparation, physical training both as leaders and commanders. The graduates evaluate relatively high (range from 2 to 6 ) the importance of mental preparation, physical training, and the cadets' preparedness to be future commanders and leaders.

The graduates assess their practical training at the lowest level. Most likely, the fact that hours of practical training and internship in military formations are insufficient contributes greatly to these results. It is very 
likely that those lower estimates are caused by the fact that the trainees do not realize the full potential of their abilities before they have actually started to implement their knowledge and skills in practice. The valuations that the fifth-year trainees give for their preparedness for future career development is shown in Figure 2.

$\square$ Average evaluation for the graduates of the National Military University

$\square$ Average evaluation for the graduates from Military logistics and fuel and lubricants

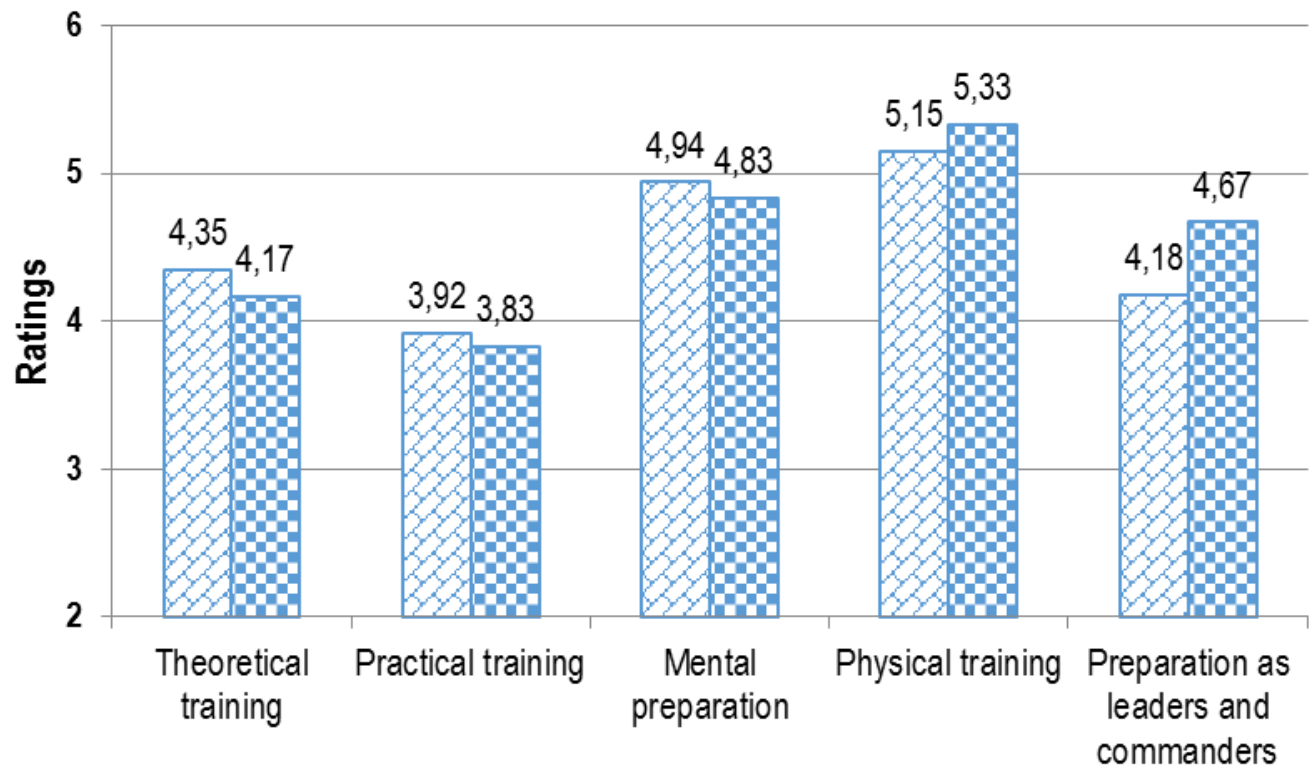

Indicators of self-estimation

Figure 2: Fifth-year trainees' self-assessment in relation to their future professional realisation

In terms of the preparedness of the future logistics officers for management activities, the most significant is the indicator which takes into account their preparedness for future commanders and leaders. In this indicator, the average self-estimation of the graduates from the Military Logistics and Fuel and Lubricants speciality is by $12 \%$ higher than the average rating given by the graduates in all specialisations at the Vasil Levski National Military University. In the other indicators, the variations are from $2 \%$ to $4 \%$, which may be considered as insignificant. It is most likely that the cadets in the Military Logistics profile have greater confidence in their preparedness for the future professional development because of studying mainly management subjects in the civilian specialty. Information about how the curriculum affects the formation of future officers as military leaders can be found in Elitsa Petrova's research. [6]

The main goal of the current study is orientated to the realisation of graduates logistics officers, complying with the fundamental objective of the Vasil Levski National Military University, namely to prepare highly qualified officers and graduates capable to perform active cognitive and research activity and who have the knowledge and skills to manage human and material resources. Figure 3 shows the realisation of logistics officers after completion of their studies at the National Military University divided by branches. 


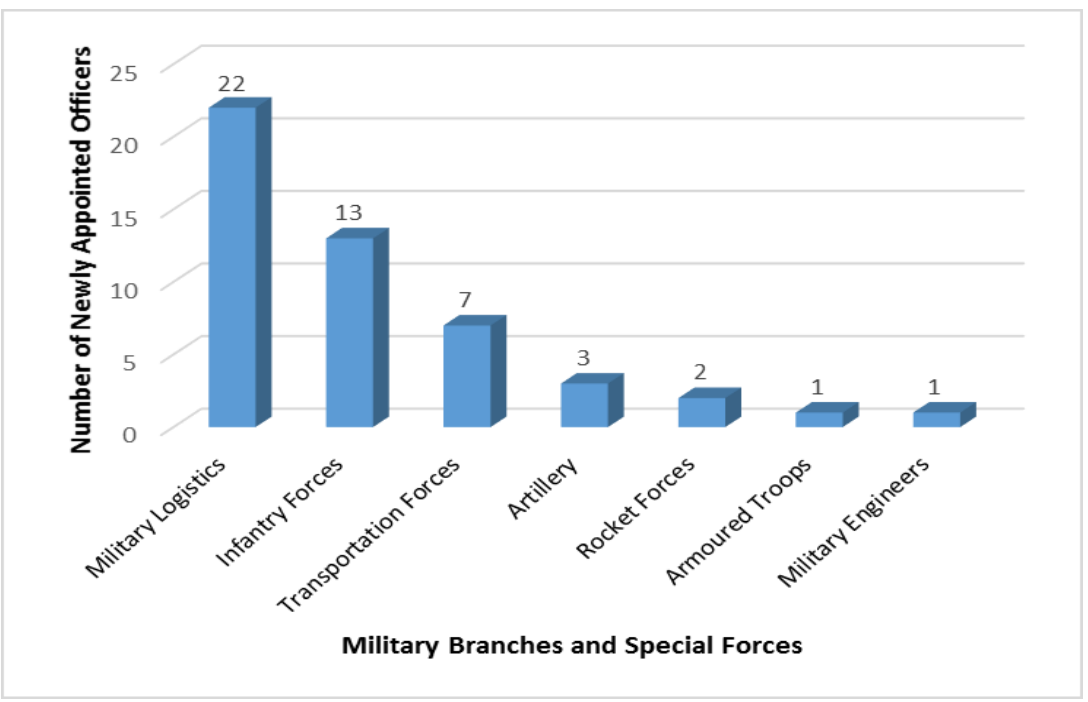

Figure 3: Realisation of the Logistics Officers by Branches

Figure 4 displays the summarised data about the realisation of officers after completion of their training at the Vasil

Levski National Military University by groups by branches.

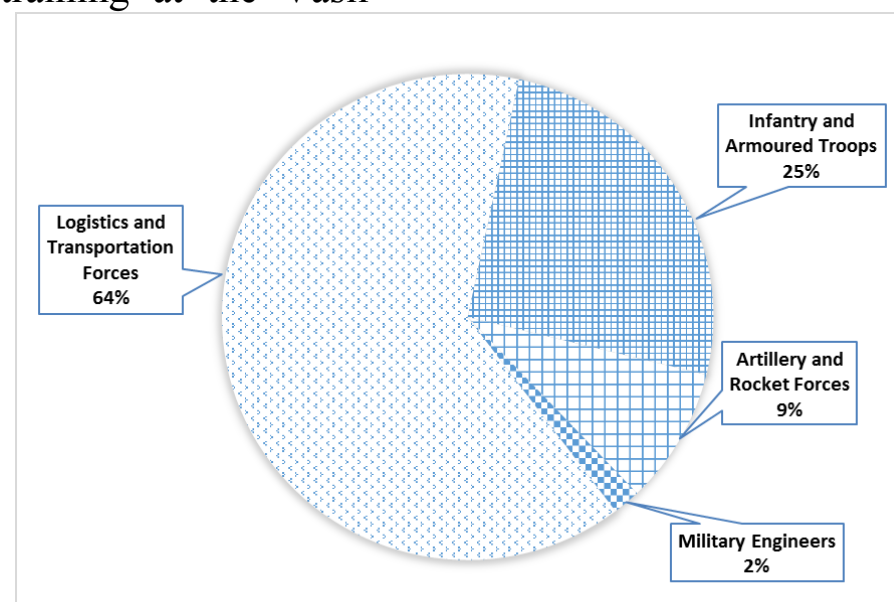

Figure 4: Summary of the implementation of logistics officers by Branches

Figure 5 shows the realisation of logistics 2011-2016. specialists in logistics units for the period of

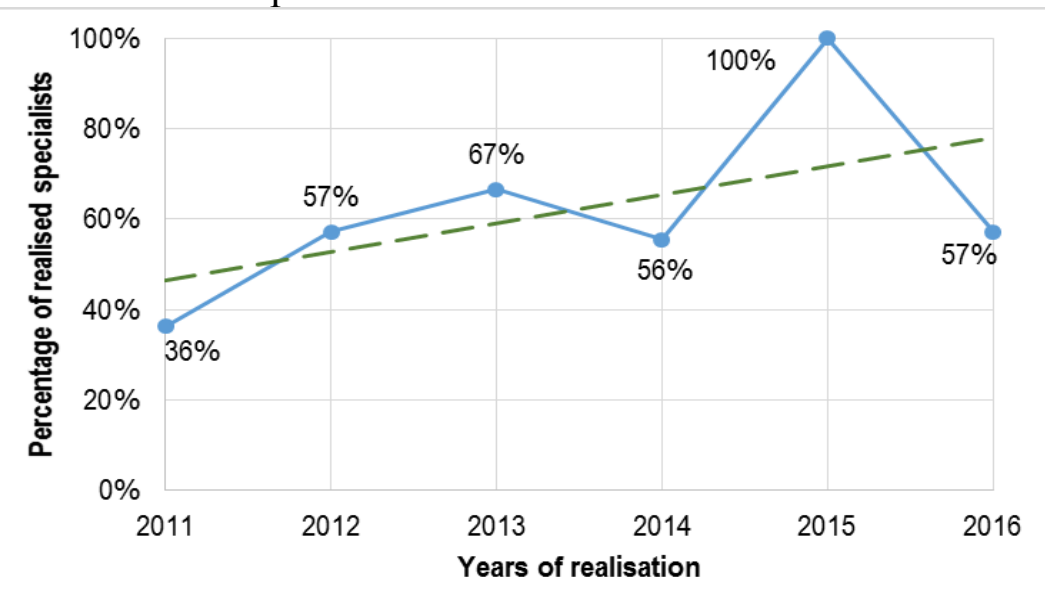

Figure 5:Realisation of logistics specialists in logistics units 
The data show that more than half of the graduate logistics specialists were assigned to logistics units over the past five years.

\section{Conclusion}

The professional military activity of logistics officers involves the acquisition of knowledge in different areas: management, law, logistics, transportation, technology, psychology, pedagogy, etc. The study and analysis of the training and the syllabus show that enhancing preparedness of the future logistics officers for management activities can be accomplished by applying a synergistic effect in arranging the courses in both the civilian and military specialties. The analysis of the realisation of the newly appointed logistics officers points a need for generalisation, systematisation and determination of approaches to structuring the content of the core curriculum which would allow improving the readiness for professional military activity. In this respect, the main focus of work should be reducing the share of general military training and increasing the share of specialised military training in logistical support.

\section{References}

[1] Angelov, Z., Psychological Problems in Warrior Activities, Ministry of Defence, Sofia, 1994.

[2] Annual Report of Military Psychology Section for Taking into Account the Opinion of Cadets at the Vasil Levski National Military University for 2015/2016 academic year.

[3] Nichev, N., Petrova, E., Professional Training of Future Logistic Officers at the National Military University of Bulgaria, Sibiu, Romania, The 21st International Conference The Knowledge-Based Organisation, Nicolae Balcescu Land Forces Academy, 11-13 June 2015, pp. 253-257.

[4] Todorkov, K., Psychological Aspects of Management of the Commander, Ministry of Defence, Sofia, 1998.

[5] Academic Plan for Training for the specialty of regulated profession Organisation and Management of Military Units at the Tactical Level with military qualification Officer for Tactical Level of Command at the Vasil Levski National Military University: 1-5-16.

[6] Petrova, E., Specific Subjects of License Academic Program - an Important Stage of Professional Development of Future Military Leaders at the National Military University, Bulgaria, The Annals of Spiru Haret University, Romania, Volume 6, issue 3, 2016, ISSN 2393-1795, ISSN-L 2068-6900, pp.113 $\div 119$. 